\title{
Are There Any Systemic Effects of the Intratympanic Administration of Dexamethasone?
}

\section{İntratimpanik Deksametazonun Sistemik Etkisi Var mı?}

Erol ŞENTÜRK id , Selahattin TUĞRUL² id, Yavuz Selim YILDIRIM², Remzi DOĞAN² id, Sabri Baki EREN² id,

Orhan ÖZTURAN ${ }^{2}$ id

'Clinic of Otorhinolaryngology Alaca State Hospital, Çorum, Turkey

${ }^{2}$ Department of Otorhinolaryngology, Bezmialem Vakif University School of Medicine, İstanbul, Turkey

\section{ABSTRACT}

Objective: Systemic absorption of steroids is reasonable because of the lipophilic nature of steroids and high vascularity of the middle ear mucosa. To date, however, of the clinical trials designed to investigate this subject, to the best of our knowledge, none has been based on objective methods. This study aims to demonstrate whether the intratympanic administration of dexamethasone has any systemic effects.

Methods: Seventeen patients had a total of five sessions of intratympanic dexamethasone treatment scheduled for every other day. The mean fasting blood glucose, serum cortisol, serum adrenocorticotrophic hormone (ACTH), and arterial blood pressure values of the patients were checked at each session before and after drug application.

Result: There were no statistically significant differences identified between the pre- and post-treatment fasting blood glucose, serum cortisol, serum ACTH, and mean arterial blood pressure.

Conclusion: This study shows that intratympanic steroids have no noticeable systemic steroidal side effects and are therefore safe to use; however, caution should be taken with patients suffering from diabetes mellitus, and they should be closely monitored.

Keywords: Inner ear diseases, intratympanic steroids, systemic effects

\section{öz}

Amaç: Orta kulak mukozasının hipervaskülasrizasyonu ve steroidlerin lipofilik yapısı dikkate alındığında, steroidlerin sisstemik absorbsiyonu düşünülmelidir. Fakat günümüze kadar yapılan klinik çalışmalarda bu absorbsiyonun etkisi objektif olarak değerlendirilememiştir. Bu çalışmanın amacı intratimpanik dexametazon uygulamasının sistemik etkilerini olup olmadığını incelemektir.

Yöntemler: İntratimpanik deksametazon tedavisi planlanan 17 hastaya iki gün arayla toplam 5 defa intratimpanik steroid yapıldı. Hastaların uygulama öncesi ve sonrası açlık kan şekeri, serum kortizol, serum ACTH (adrenocorticotrophic hormone) değerlerine ve arteryel tansiyonlarına bakıldı.

Bulgular: Hastaların intratimpanik tedavi öncesi ve sonrası açlık kan şekeri, serum kortizol, serum ACTH ve tansiyon arteryellerinde istatistiksel olarak anlamlı bir fark saptanmadı.

Sonuç: İntratimpanik steroid, anlamlı bir sistemik yan etki oluşturmamaktadır ve güvenlidir, ancak yine de DM olan hastalarda dikkat edilmesi ve yakın takip edilmesi gereklidir.

Anahtar Kelimeler: İntratimpanik steroid, sistemik etki, iç kulak hastalıkları

\section{Introduction}

After the introduction of the concept of autoimmune hearing loss by McCabe (1, 2) in $1979(3,4)$, corticosteroids began to be used systemically for the treatment of many inner ear diseases. Sometime later, intratympanic corticosteroid treatment was also introduced. Examples of immune-mediated inner ear diseases include post-meningitis labyrinthitis, Cogan syndrome, idiopathic sudden hearing loss, Meniere's disease, and progressive sensory-neural hearing loss (5).

Systemic steroid treatment constitutes the standard of care in the treatment of autoimmune inner ear diseases. However, longterm high-dose systemic steroid treatment has several well-known side effects, such as weight gain, high blood pressure, and Cushing's syndrome. Furthermore, the passage of the steroid through the blood-perilymphatic barrier is limited; therefore, determining nontoxic doses presents the challenge of obtaining an ideal perilymphatic level. On the other hand, intratympanic steroid administration theoretically has two advantages. The first is that it creates a higher perilymphatic concentration

This article was presented as an oral presentation at 36th National Otolaryngology and Head and Neck Surgery Congress (5-9 November 2014, in Antalya, Turkey) Bu makale 36.Ulusal Kulak Burun Boğaz ve Baş Boyun Cerrahisi Kongresi'nde(5-9 Kasım 2014, Antalya, Türkiye) sözlü sunum olarak sunulmuştur.

Cite this article as: Şentürk E, Tuğrul S, Yıldırım YS, Doğan R, Eren SB, Özturan O. Are There Any Systemic Effects of the Intratympanic Administration of Dexamethasone? Bezmialem Science 2018; 6(3): 186-90. 
than is possible with systemic treatment since it passes through the round window membrane. The second advantage is that it is considered to have low toxicity and few systemic effects (5).

Studies in the field of intratympanic steroid administration have been conducted primarily on the basis of animal experiments (5-8). The relatively few clinical studies were conducted solely on diabetic patients $(9,10)$. Several studies report that the intratympanic steroid administration is safe, but it has been claimed that it causes hyperglycemia (11). So, does intratympanic steroid treatment indeed have any systemic effects or not? If yes, how safe is it? This study aims to answer these questions on the basis of a prospective clinical study conducted on a patient population including both diabetic and non-diabetic patients.

\section{Methods}

Included in this study were 24 patients (age range 41-69) who, between June 2013 and December 2013, presented to the Otolaryngology Department of the Bezmialem Vakif University University Hospital and were scheduled for intratympanic dexamethasone treatment. The study was initiated following approval granted by the local ethics committee. (050.01.04/557) The inclusion criteria were the following: patients suffering from sudden hearing loss, Meniere's disease, acoustic trauma, and that they were not taking any sistemic steroid medication. Contraceptives, alcohol, cimetidine, phenytoin, estrogens, tetracycline, and kidney disease were the exclusion criteria. Each patient who underwent an ear-nosethroat examination and gave informed consent was accepted into the study. Fasting blood glucose, serum cortisol, and the adrenocorticotrophic hormone (ACTH) levels, as well as the arterial blood pressure readings of all patients, were measured at 8:30 in the morning before the treatment. Every 2 days, each patient received $1 \mathrm{~mL}$ dexamethasone sodium phosphate $4 \mathrm{mg} / \mathrm{mL}$ via the tympanic membrane. With patients in supine position, the injection was administered in the posterior-superior quadrant of the tympanic membrane, following an application of a topical anesthetic. After the injection, the patients remained prone for 30 minutes and were instructed not to swallow during that time. To monitor blood pressure, the subjects were instructed to have their arterial blood pressure measured and recorded in the morning and evening of every day. At the end of the treatment-at the same time in the morning on the day after the last dose-their fasting blood glucose, serum cortisol, and ACTH levels, as well as arterial blood pressure readings, were measured again.

\section{Statistical analysis}

The Statistical Package for the Social Sciences for Windows (version 11.5) (SPSS Inc.; Chicago, IL, USA) was used for the statistical analysis to determine intra- and inter-group differences. The pre- and post-intratympanic injection values were compared using the Wilcoxon signed-rank test. The data were expressed as the mean \pm standard deviation. A p-value of $<0.05$ was considered to be statistically significant.

\section{Results}

The mean age of patients included in the study was 49.4 (range 41-69). Twelve of the patients were male, and 12 were female. Their mean fasting blood glucose results were 97.4 $\mathrm{mg} / \mathrm{dL}$ (81-143) for pre-treatment and $91.3 \mathrm{mg} / \mathrm{dL}$ (76-155) for post-treatment. A comparison of these two values showed no statistically significant difference $(\mathrm{p}=0.116)$.

When the ACTH levels were compared, the pre-treatment mean was $27 \mathrm{pg} / \mathrm{mL}$ (11.7-60), and the post-treatment mean was $23.3 \mathrm{pg} / \mathrm{mL}$ (1.2-63). A comparison of these two values disclosed no statistically significant difference $(\mathrm{p}=0.480)$.

The mean pre-treatment cortisol level was $15.8 \mathrm{ug} / \mathrm{dL}$ (7.257.6), and the mean post-treatment cortisol level was $9.6 \mathrm{ug} /$ $\mathrm{dL}(0.2-23)$. When the cortisol levels were compared, the values were seen to have dropped; however, this drop was not statistically significant $(\mathrm{p}=0.058)$.

The mean arterial pressure values were $97.5 \mathrm{mmHg}(83-$ 113.3) before the treatment and $97.5 \mathrm{mmHg}(80-123.3)$ after the treatment. Compared, these values were not statistically different $(\mathrm{p}=0.863)$ (Table 1 and Figure 1). The mean body mass index level was 24.7 (19-29).

Table 1. Parameters-pre-treatment and post-treatment*

\begin{tabular}{|c|c|c|c|c|c|c|}
\hline \multicolumn{2}{|l|}{ Parameters } & Mean $\pm S D$ & $95 \% \mathrm{CL}$ & Min. & Max. & Statistic (p) \\
\hline \multirow[t]{2}{*}{ Fasting blood glucose (mg/dL) } & Pre-treatment & $97.4 \pm 17.11$ & $88.6-106.2$ & 81.0 & 143.0 & $p=0.116$ \\
\hline & Post-treatment & $91.3 \pm 18.6$ & $81.7-100.9$ & 76.0 & 155 & \\
\hline \multirow[t]{2}{*}{ Cortisol ( $\mu \mathrm{g} / \mathrm{dL})$} & Pre-treatment & $15.8 \pm 11.66$ & $9.8-21.8$ & 7.2 & 57.6 & $p=0.058$ \\
\hline & Post-treatment & $9.6 \pm 5.64$ & $6.7-12.5$ & 0.2 & 23.0 & \\
\hline \multirow[t]{2}{*}{ Mean arterial pressure $(\mathrm{mmHg})$} & Pre-treatment & $97.5 \pm 10.53$ & $92.1-102.9$ & 83.0 & 113.3 & $p=0.863$ \\
\hline & Post-treatment & $97.5 \pm 12.29$ & $91.2-103.8$ & 80.0 & 123.3 & \\
\hline \multirow[t]{2}{*}{ ACTH (pg/mL) } & Pre-treatment & $27.0 \pm 11.75$ & $20.9-33.0$ & 13.6 & 60.0 & $p=0.480$ \\
\hline & Post-treatment & $23.3 \pm 14.08$ & $16.1-30.5$ & 1.2 & 63.0 & \\
\hline
\end{tabular}



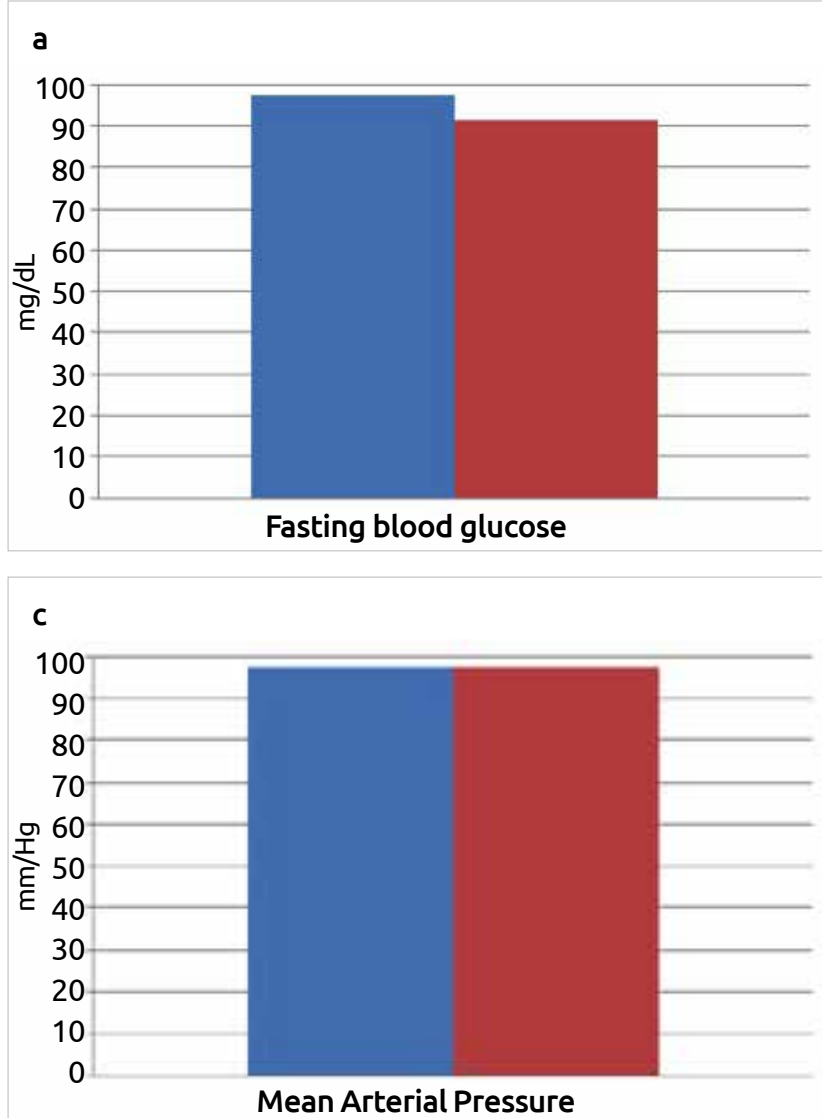

b

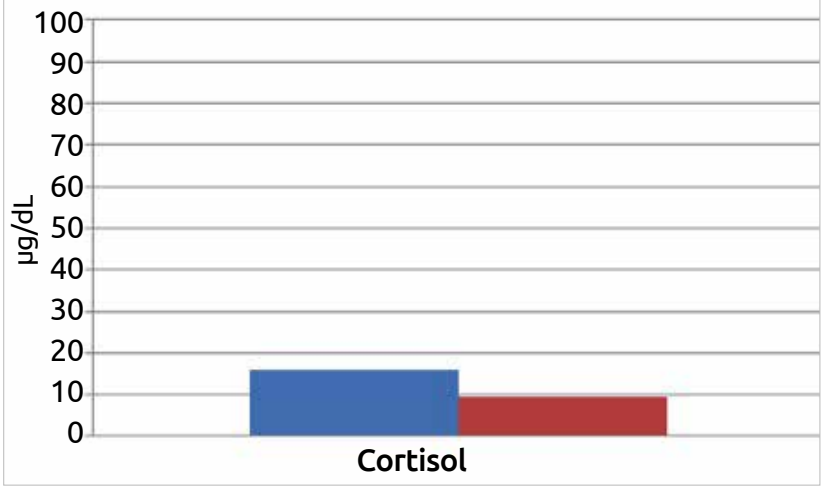

d

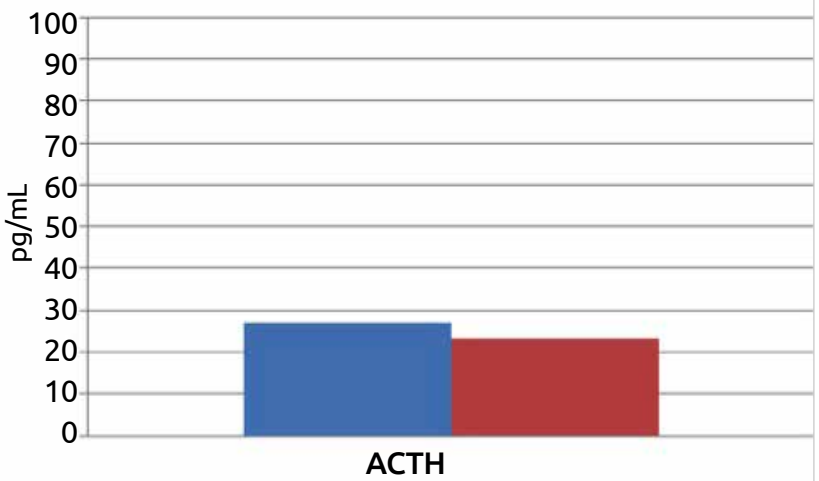

Figure 1. a-d. (a) Fasting blood glucose-pre-treatment and post-treatment. (b) Cortisol-pre-treatment and posttreatment. (c) Mean arterial pressure-pre-treatment and post-treatment. (d) ACTH-pre-treatment and post-treatment ACTH: adrenocotricotrophic hormone

Since the group was not homogeneous, no audiological comparisons with respect to the intratympanic treatment indication could be made.

No patients developed permanent perforations during the follow-up after the injection.

\section{Discussion}

Corticosteroids constitute a group of drugs frequently used for many indications, particularly for autoimmune and chronic inflammatory diseases (12). However, extreme care is needed because of their serious systemic side effects, which can range from central fattening, dyslipidemia, muscle mass loss, and hyperglycemia to diabetes mellitus (13). To protect against these negative side effects, intratympanic administration has in recent years become the most popular treatment modality (5).

Several animal studies have demonstrated that intratympanic steroid administration reaches a higher perilymphatic concentration compared to oral or intravenous (IV) steroid administration $(5,6)$ and that the injected steroid is widely dispersed inside the spiral ligament, basilar membrane, organ of Corti, and spiral ganglion (14). The first clinical administration of in 1991 for the treatment of Meniere's disease (15). Since then, many articles on the efficacy of intratympanic steroid treatment have been published, thus popularizing this treatment.

Our review of the literature in English found no clinical studies conducted in relation to the systemic safety of intratympanic steroids, despite the investigation of the systemic effects of steroid-containing nasal tampons (16) and epidural steroid injections (17). Two studies compared the blood sugar values of exclusively diabetic patients. Kakehata et al. administered either IV steroids or intratympanic steroids to a total of 21 patients who had had a sudden loss of hearing and diabetes. When compared, the intratympanic steroid group had a higher rate of improvement, and no negative systemic side effects in terms of blood sugar were observed (9).

Han et al. (10) conducted a study in which 114 diabetes mellitus patients with sudden loss of hearing were divided into three groups. The first group received oral prednisolone, the second group IV prednisolone, and the third group intratympanic dexamethasone. Then their hearing gains were checked. In all three groups, hearing gains were the same. On the other hand, whereas no raise in blood sugar levels was noted in the intratympanic dexamethasone group, because of uncontrollable hyperglycemia, the treatment had to be discontinued for 
one patient in the oral prednisolone group and for two in the IV prednisolone group (10). Likewise, Gallegos-Constantino et al. (11) had to discontinue treatment for a diabetic patient who became hyperglycemic after receiving intratympanic dexamethasone for the sudden loss of hearing. They reported that caution should be taken with diabetic patients.

In our study, a random patient population was selected to investigate systemic effects on patients scheduled for intratympanic steroid treatment. The reasons for intratympanic steroid administration were as follows: sudden loss of hearing (10 patients), Meniere's disease (2 patients), tinnitus (2 patients), and acoustic trauma (4 patients). At the same time, 3 patients were being treated for diabetes and 2 for hypertension. The pre- and post-treatment blood pressure, blood sugar, cortisol, and ACTH values of the patients were compared to investigate the systemic effects of intratympanic steroids. Even though the serum cortisol levels were observed to have dropped, this decrease was not found statistically significant (Perhaps it would have been if our patient population had been larger). As for the serum ACTH, fasting blood sugar, and mean arterial values, no statistically significant differences were found between the pre- and post-treatment readings. A patient who was known to be diabetic developed hyperglycemia on Day 5 of the treatment; however, it was put under control and treatment discontinuation was not necessary. The fact that the study was conducted with a small patient population could be seen as a limitation. On the other hand, the patients had a variety of diseases and a wide age range, which enhances the strength of our study.

One limitation in the current study is the lack of placebo group that did not take the drug intratympanically. Because the intratympanic application is painful and hazardous, constituting a group without drug was regarded as unethical.

\section{Conclusion}

So, does intratympanic steroid treatment indeed have any systemic effects? Intratympanic steroid treatment, which is complementary to or an alternative to systemic steroid treatment, is safer with respect to its side effects. In our study population, nothing noticeable arose. We reiterate the caution given by others, however, that care must be taken with diabetic patients.

Ethics Committee Approval: Ethics committee approval was received for this study from the ethics committee of Bezmialem Vakif University (050.01.04/557).

Informed Consent: Written informed consent was obtained from patient who participated in this study.

Peer-review: Externally peer-reviewed.

Author Contributions: Concept - E.Ş., S.T.; Design - E.Ş., S.T., O.Ö.; Supervision - O.Ö., S.B.E.; Resources - Y.S.Y., S.B.E.; Ma- terials - E.Ş., S.T., R.D.; Data Collection and/or Processing - E.Ş.; Analysis and/or Interpretation - E.Ş., S.B.E., O.Ö.; Literature Search - R.D., Y.S.Y.; Writing Manuscript - E.Ş., R.D.; Critical Review - O.Ö., S.B.E., S.T.

Acknowledgements: The authors appreciate the contributions and editorial assistance made by S. Delacroix, a native English speaker.

Conflict of Interest: Authors have no conflicts of interest to declare.

Financial Disclosure: The authors declared that this study has received no financial support.

Etik Komite Onayı: Bu çalışma için etik komite onayı Bezmialem Vakıf Universitesi'nden (050.01.04/557) alınmıştır.

Hasta Onamı: Yazılı hasta onamı bu çalışmaya katılan hastadan alınmıştır.

Hakem Değerlendirmesi: Dış bağımsız.

Yazar Katkıları: Fikir - E.Ş., S.T.; Tasarım - E.Ş., S.T., O.Ö.; Denetleme - O.Ö., S.B.E.; Kaynaklar - Y.S.Y., S.B.E.; Malzemeler - E.Ş., S.T., R.D.; Veri Toplanması ve/veya İşlemesi - E.Ş.; Analiz ve/veya Yorum - E.Ş., S.B.E., O.Ö.; Literatür Taraması - R.D., Y.S.Y.; Yazıyı Yazan - E.Ş., R.D.; Eleştirel İnceleme - O.Ö., S.B.E., S.T.

Teşekkür: Yazarlarlar olarak, yaptığı katkı ve yorumlardan ötürü ana dili İngilizce olan S. Delacroix’e teşekkür ederiz.

Çıkar Çatışması: Yazarlar çıkar çatışması bildirmemişlerdir.

Finansal Destek: Yazarlar bu çalışma için finansal destek almadıklarını beyan etmişlerdir.

\section{References}

1. McCabe BF. Autoimmune sensorineural hearing loss. Ann Otol Rhinol Laryngol 1979; 88: 585-9. [CrossRef]

2. McCabe BF. Autoimmune inner ear disease: results of therapy. Adv Otorhinolaryngol 1991; 46: 78-81. [CrossRef]

3. Harris JP. Experimental immunology of the inner ear. Adv Otorhinolaryngol 1991; 46: 26-33. [CrossRef]

4. Hughes GB, Kinney SE, Barna BP, Calabrese LH. Practical versus theoretical management of autoimmune inner ear disease. Laryngoscope 1984; 94: 758-66. [CrossRef]

5. Chandrasekhar SS, Rubinstein RY, Kwartler JA, Gatz M, Connelly PE, Huang E, et al. Dexamethasone pharmacokinetics in the inner ear: Comparison of route of administration and use of facilitating agents. Otolaryngol Head Neck Surg 2000; 122: 521-8. [CrossRef]

6. Parnes LS, Sun AH, Freeman DJ. Corticosteroid pharmacokinetics in the inner ear fluids: an animal study followed by clinical application. Laryngoscope 1999; 109: 1-17. [CrossRef]

7. Plontke SKR, Salt AN. Quantitative interpretation of corticosteroid pharmacokinetics in inner fluids using computer simulations. Hear Res 2003; 182: 34-42. [CrossRef]

8. Bachmann G, Su J, Zumegen C, Wittekindt C, Michel O. Permeabilitat der runden fenster membran fur prednisolon-21-hydrogensuccinat. HNO 2001; 49: 538-42. [CrossRef] 
9. Kakehata S, Sasaki A, Oji K, Futai K, Ota S, Makinae K, et al. Comparison of intratympanic and intravenous dexamethasone treatment on sudden sensorineural hearing loss with diabetes. Otol Neurotol 2006; 27: 604-8. [CrossRef]

10. Han CS, Park JR, Boo SH, Jo JM, Park KW, Lee WY, et al. Clinical efficacy of initial intratympanic steroid treatment on sudden sensorineural hearing loss with diabetes. Otolaryngol Head Neck Surg 2009; 141: 572-8. [CrossRef]

11. Gallegos-Constantino V, Cervera-Paz FJ, Salvador J, Ba FK, Perez-Fernandez N. Hyperglycemia after intratympanic dexamethasone treatment in a diabetic patient. Rev Laryngol Otol Rhinol (Bord) 2011; 132: 153-5.

12. Yuen KC, McDaniel PA, Riddle MC. Twenty-fourhour profiles of plasma glucose, insulin, C-peptide and free fatty acid in subjects with varying degrees of glucose tolerance following short-term medium-dose prednisone $(20 \mathrm{mg} /$ day $)$ treatment: evidence for differing effects on insulin secretion. Clin Endocrinol 2012; 77: 224-32. [CrossRef]
13. Van Raalte DH, Ouwens DM, Diamant M. Novel insights into glucocorticoid-mediated diabetogenic effects: towards expansion of therapeutic options? Eur J Clin Invest 2009; 39: 81-93. [CrossRef]

14. Hargunani CA, Kempton B, DeGagne JM, Trune DR. Intratympanic injection of dexamethasone: time course of inner ear distribution and conversion to its active form. Otol Neurotol 2006; 27: 564-9. [CrossRef]

15. Itoh A, Sakata E. Treatment of vestibular disorders. Acta Otolaryngol Suppl 1991; 481: 617-23. [CrossRef]

16. Hong SD, Kim JH, Dhong HJ, Kim HY, Chung SK, Chang YS, et al. Systemic effects and safety of triamcinolone-impregnated nasal packing after endoscopic sinus surgery: a randomized, double-blinded, placebo-controlled study. Am J Rhinol Allergy 2013; 27: 407-10. [CrossRef]

17. Bellini M, Barbieri M. Systemic effects of epidural steroid injections. Anaesthesiol Intensive Ther 2013; 45: 93-8. [CrossRef] 